\title{
The Process of Globalization of the Infrastructure Institutes on the Financial Markets in Developed Countries
}

\author{
Adamova Karine \\ Department of Financial Markets and Financial Engineering, Financial University, Russia
}

Copyright (C) 2015 Horizon Research Publishing All rights reserved.

\begin{abstract}
The process of globalization of the world economy affects all areas of the world financial market and considerably affected and even forms the main trends in the national financial markets of developed and developing countries. Globalization promotes greater openness of financial markets, facilitating access to national markets of capitals, unification of norms and rules of realization of operations, regulation and supervision of financial sphere, standardization of requirements to the transaction and payment and settlement servicing of participants of operations.
\end{abstract}

Keywords Financial Markets, Globalization, Developed Countries, Toronto Stock Exchange, London Stock Exchange (LSE), Deutsche Boerse and NYSE Euronext, Transatlantic Stock Exchange, Mergers and Acquisitions

\section{Introduction}

Globalization of the financial sector of the global economy, which is based on the development of information technology and tele-communication systems and channels of communication contributes to the internationalization and integration of national financial markets. This is expressed continuous improvement technologies and the development of institutions of the financial market infrastructure, the facilitation of cross-border transfers and transactions, unification of the rules of settlement and standardizes financial transactions institutions trading and accounting and settlement infrastructure.

In the last quarter of the twentieth century simultaneously with the unification of the processes of functioning of the national stock markets of developed and developing countries is started and the global process of internationalization, passed in the beginning of XXI century in total globalization. Internationalization and globalization of financial markets is accompanied by institutional changes, in particular, the creation of a transnational organizer - trade, primarily stock exchanges. And it occurs primarily in the framework of international transnational M\&A transactions, as well as entering into strategic alliances for the implementation of business strategies in certain markets, i.e. cooperation of financial institutions in these global processes has many forms.

\section{Methodology and Discussion}

Of great interest are some of the most important integration processes taking place in the stock markets of developed countries and significantly influenced the formation of the modern stock architecture of financial markets of these countries. After creating American NYSE together with Euronext world's first transatlantic stock exchange, NASDAQ and OMX Nordic agreed on the establishment of the second trading platforms, and it seemed that the redistribution of the global exchange market completed. But that was just the beginning of the consolidation processes in the world.

The Board of Directors of British LSE 21 June 2007 defined the details of the offer on purchase of Italian Borsa Italiana. [1, Sukumar N., 2007] Initially the amount that London was ready to offer for the Italian was about one and a half billion eEuros. This LSE wanted to buy Borsa Italiana its shares rather than cash. But the fight became involved NYSE - Euronext, which has offered for the asset of around half a billion eEuros. [2, Macdonald A., 2007]

However, the London Stock Exchange (LSE) and the Italian Borsa Italiana, on June 23, 2007 announced the merger. In the course of the transaction was formed company worth 5.8 billion Euros. British exchange offered by 4.9 its shares for each share of Borsa Italiana. The deal amounted to 1.63 billion Euros. On completion of the transaction LSE shareholders belonged 72 and shareholders Borsa Italiana - $28 \%$ of the combined company. It was expected that the merger will allow in fiscal 2009 to increase the revenues of at least $10 \%$ annually due to the 
merger of stockbrokers will save about 29 million Euros. However, in the course of transaction arose and other obstacles. The fact that shares of the London stock exchange in 2007 was owned by:

- Nightingale Acquisition Limited (дочерняякомпания NASDAQ) 30\%

- Bear Stearns International Trading Limited 12.0\%

- Kinetics Asset Management Inc./Horizon Asset Management Inc. 7.1\%

- Credit Suisse Securities (Europe) Limited/ Credit Suisse International 3.8\%.

Thus, when buying Borsa Italiana for shares LSE it was necessary to conduct additional issue of shares that would have led to a dilution of existing shares of majority shareholders. Therefore, the NASDAQ voting shareholders have exercised their right and blocked the deal. As a result of its implementation, their share would already be $22 \%$, not $30 \%$, and they could not block the decisions of the Board of Directors and policy exchange in General. Relations between NASDAQ and LSE has escalated in 2006, when the Americans tried to take over the London stock exchange, but the leadership of the LSE rejected all proposals of the NASDAQ. Then the American stock exchange launched a hostile buying up shares of the London competitor, having managed to accumulate 30 percent of securities. In order to obtain a positive decision on this issue LSE had to pay its shareholders about 1 billion US dollars.

In December 2007, the Toronto Stock Exchange has agreed to buy Montreal Exchange. Thus, the United two largest exchanges Canada. [3] The deal amounted to $\$ 1.3$ billion canadian dollars (about 1.3 billion US dollars). The merger allowed to create a unified exchange share trading and derivative financial instruments. In addition, canadian exchange with it avoided a potential takeover by foreign companies.

Besides a large number of mergers and acquisitions, 2007-2008 has become the engine for the development of stock exchanges in the direction of expansion of its branch network. In 2008 the London stock exchange has opened its branch in Beijing. Previously about the opening of their subsidiaries in China said other major world stock exchange - NYSE and NASDAQ. All leading world's stock exchanges are trying to attract Chinese companies on their trading platform, as the country's economy growing at more than 10 percent a year. Because of this, shares of Chinese corporations in high demand on the market.

This process of redistribution of the European stock market has not ended. In 2008, NASDAQ announced their intention to create in England exchange - competitor of the LSE. At the same time, nine of the largest world investment banks announced the establishment of the electronic trading platform Turquoise. In the list of investors Turquoise joined Credit Suisse and UBS, Deutsche Bank, and the American Citigroup, Goldman Sachs, Merrill Lynch and Morgan Stanley, French BNP Paribas, Societe Generale. The number of issuers on the site grew speedily: if in August 2008 it was traded only 10 companies a month already amounted to 1,300 .

In 2010 was the Union of the London stock exchange and its main competitor - an electronic platform Turquoise. By results of trades $60 \%$ of shares formed by the merger of the company remained at the LSE, and the remaining $40 \%$ of the current founders Turquoise. LSE also invested 20 million pounds sterling ( 22.5 million Euros) in Turquoise, which in 2008 became unprofitable 15.7 million pounds loss.[4, Sunderland R., 2009] The new stock exchange was merged with the European trading area of Baikal, to create it LSE returned in June 2009. Baikal operates on a system of so-called «hidden pool» (dark pool, allowing bidders to trade stocks anonymously, without publishing the information on its strategy, and without changing the value of the securities, as is done on a regular exchanges.

The following active year for the consolidation was the year 2009. Oon the 9th of February it became known that the major transactions of merge and absorption in the market of world stock exchanges. British LSE agreed to buy the Toronto stock exchange and Deutsche Boerse approached even more ambitious agreement on purchase American-European trading platform of NYSE Euronext. The yearning for unity was largely due to the desire to strengthen its position in the rapidly growing market of derivative securities (derivatives) - first of all, futures and options. Only the merger of Deutsche Boerse and NYSE Euronext brought together for 11 of the derivatives markets around the world. What is characteristic, the control of this industry in the United Company concentrated exactly in Frankfurt, while global governance listing and American deals with cash would have remained in New York. A preliminary deal was such that $60 \%$ of the merged company received exactly the Germans.

On the 1st of February 2012 became known that the European Commission has not given permission for the merger of the stock exchanges-NYSE Euronext and Deutsche Boerse. The European regulator concluded that the merger of the stock exchanges will lead to restriction of competition. Request to merge was rejected by the regulator, even though both stock markets were ready to make concessions to the Commission and to sell part of its business. The merger was approved by shareholders of both exchanges, as well as the regulatory authorities in Germany, Luxembourg and the United States. The deal was to be established largest in the world of exchange on sales volume and net revenue.

Also a landmark deal of the year 2011 was the purchase by the group TMX 16\% stake in the Bermuda stock exchange, which is one of the largest offshore exchanges in the world and always attractive for investors, because it is more flexible listing rules and act in the legislative constraints typical for stock exchanges of developed countries.

\section{Results}

Studying the integration processes of the exchange sector 
of developed countries since the early 1990's of the 20th century and to this day, it can be noted that much has changed specifics of transactions. If prior to the 2006 transaction was actively been at the national level for the last 5 years in developed countries is dominated by transactions transboundary.

In many European countries now operates in one exchange, which, in turn, belongs to one or another Intercontinental stock exchange group. Rating of stock exchanges WFE and ratings futures exchanges head of the stock exchange of the United States, and the difference in the volumes of trade at the stock exchange group and individual institutions is enormous. The interesting situation on the financial market of Japan actively pursues a policy of national Association of stock exchanges and is still too closed to reach the international level.

It is also worth noting that there is a tendency management by the exchange through the purchasing its shares. Significantly increased the influence of the new industrial countries of the world - in the course of the research was the analysis of the share capital of the LSE and Deutsche Boerse and found that exchanges of developed countries possess the holdings of the UAE and Qatar.

\section{REFERENCES}

[1] Sukumar, N. Borsa Italiana's board resolves doubts about LSE bid (Update 1) // N. Sukumar, A. Migliaccio. : http://www.bloomberg.com/apps/news?pid=newsarchive\&si $\mathrm{d}=\mathrm{a} . \mathrm{xWD5}$ 3.NZY, Freequent. - Placed 22nd of June 2007.

[2] Macdonald, A. Borsaltaliana's Decision: LSE or NYSE? / A. Macdonald, A. Lucchetti // L., N-Y.: The Wall Street Journal: http://online.wsj.com/article/SB1 18247199215144246.html? mod=home_whats_news_us, Freequent. - Placed 22nd of June 2007.

[3] Toronto, Montreal Exchanges announce $\$ 1,3$ bln merger: http://www.cbc.ca/news/business/story/2007/12/10/stock-ex change.html, Freequent. - Placed 10th of December 2007.

[4] Sunderland, R. London Stock Exchange poised to seal merger with Turquoise / R. Sunderland // L. The Observer.: http://www.guardian.co.uk/business/2009/dec/20/london-sto ck-exchange-turquoise-talks, Freequent. - Placed 20th of December 2009. 